\title{
THE FEATURES OF THE PREVALENCE OF TRIGLYCERIDEMIA AND ITS IMPORTANCE IN DEVELOPMENT OF EXCESS WEIGHT AND OBESITY IN ELDERLY POPULATION (population research)
}

\author{
CHOBANOV RAFIG E., D. Med. Sci., professor, the Head of the Department of public health and health management \\ of Azerbaijan Medical University, Azerbaijan, AZ1022, Baku, Gasimzade str., 14, tel. (+994)125-64-93-37, \\ e-mail:mic_amu@mail.ru
}

GADZHIYEVA YAGUT G., C. Med. Sci., senior lecturer of the Department of public health and health management of Azerbaijan Medical University, Azerbaijan, AZ1022, Baku, Gasimzade str., 14, tel. (+994)125-64-93-37, e-mail: mic_amu@mail.ru

\begin{abstract}
Aim. The aim of the research was to study of the prevalence of hypertriglyceridemia and its importance in development of excess weight and obesity at the population level. Material and methods. A survey of 2013 inhabitants was conducted in Baku (SF-36). At the same time finger blood sample was taken to measure triglyceride level. Accutrendplus portative device (test system) was applied. Body weight was assessed using the World Health Organization index. Results and discussion. Hypertriglyceridemia was found in $(33,7 \pm 1,1) \%$ of inhabitants. In $(24,5 \pm 1,0) \%$ persons triglyceride level was $(1,7 \pm 2,2) \mathrm{mmol} / \mathrm{l}$. It was $(2,3-5,6) \mathrm{mmol} / \mathrm{l}$ in $(7,7 \pm 0,6) \%$ of the participants. $5,7 \mathrm{mmol} / \mathrm{l}$ and greater values was seen in $(1,5 \pm 0,2) \%$ of them. Excess body weight was registered in $(18,9 \pm 0,9) \%$ of inhabitants. Different degrees of obesity were observed in $(29,8 \pm 1,0) \%$ of them. It was determined that body weight depends on triglyceride level. Triglyceride level was higher than $2,3 \mathrm{mmol} / \mathrm{l}$ in all cases of obesity. Conclusion. Hypertriglyceridemia, when combined with low physical activity and inadequate nutritional behavior, promotes development of excess body weight and obesity. Hypertriglyceridemia and obesity increase the risk of cardiovascular disease development.

Key words: interdependence, hypertriglyceridemia, obesity, population research.

For reference: Chobanov RE, Gadzhieva YaG. The features of the prevalence of triglyceridemia and its importance in development of excess weight and obesity in elderly population (population study). The Bulletin of Contemporary Clinical Medicine. 2020; 13(5): 40-45. DOI: 10.20969/VSKM.2020.13(5).40-45.
\end{abstract}

\section{ОСОБЕННОСТИ РАСПРОСТРАНЕНИЯ ТРИГЛИЦЕРИДЕМИИ И ЕЕ ЗНАЧЕНИЕ В ФОРМИРОВАНИИ ИЗБЫТОЧНОГО ВЕСА И ОЖИРЕНИЯ СРЕДИ ПОЖИЛОГО НАСЕЛЕНИЯ (популяционное исследование)}

ЧОБАНОВ РАФИК ЭНВЕР оглы, докт. мед. наук, профессор, зав. кафедрой общественного здоровья и здравоохранения Азербайджанского медицинского университета, Азербайджан, AZ1022, Баку, ул. Э. Гасымзаде, 14, тел. (+994)125-64-93-37, e-mail: mic_amu@mail.ru

ГАДЖИЕВА ЯГУТ ГАДЖИАЛИ кызы, канд. мед. наук, старший преподаватель кафедры общественного здоровья и здравоохранения Азербайджанского медицинского университета, Азербайджан, АZ1022, Баку, ул. Э. Гасымзаде, 14, тел.(+994)125-64-93-37, e-mail: mic_amu@mail.ru

\begin{abstract}
Реферат. Цель - изучение распространенности гипертриглицеридемии и ее значение в формировании лишнего веса и ожирения на популяционном уровне. Материал и методы. Был проведен опрос 2013 жителей Баку с помощью опросника SF-36, при этом у них была взята кровь из пальца для определения триглицеридов. Использовали портативное устройство (тест-систему) Accutrend-plus. Индекс массы тела рассчитывался по рекомендациям Всемирной организации здравоохранения. Результаты и их обсуждение. Гипертриглицеридемия выявлена у $(33,7 \pm 1,1) \%$ жителей, уровень триглицеридов составил $(1,7 \pm 2,2)$ ммоль/л у $(24,5 \pm 1,0) \%$ из них, 2,3-5,6 ммоль/л - у $(7,7 \pm 0,6) \%, 5,7$ ммоль/л и более - у $(1,5 \pm 0,2) \%$ из них. Избыточная масса тела отмечена у $(18,9 \pm 0,9) \%$ жителей, ожирение различной степени выраженности - у $(29,8 \pm 1,0) \%$ из них. Установлено, что масса тела зависит от уровня триглицеридов. Уровень триглицеридов был выше 2,3 ммоль/л во всех случаях ожирения. Выводы. Гипертриглицеридемия в сочетании с низкой физической активностью и неправильным питанием способствует формированию избыточной массы тела и ожирению. Гипертриглицеридемия и ожирение увеличивают риск развития сердечно-сосудистых заболеваний.

Ключевые слова: взаимосвязь, гипертриглицеридемия, ожирение, популяционное исследование.

Для ссылки: Чобанов, Р.Э. Особенности распространения триглицеридемии и ее значение в формировании избыточного веса и ожирения среди пожилого населения (популяционное исследование) / Р.Э. Чобанов, Я.Г. Гаджиева // Вестник современной клинической медицины. - 2020. - Т. 13, вып. 5. - С.40-45. DOI: 10.20969/ VSKM.2020.13(5).40-45
\end{abstract}

$\mathrm{R}$ elevance. Cardiovascular pathology is one of the main causes of mortality in all developed countries. WHO (World Health Organization) estimates that by 2030 about 23,6 million people will die of cardiovascular disease every year [1]. Despite the introduction of new treatments, the mortality rate has risen over the last 6-8 years and remains uchanged [2]. Therefore, it is important to look for additional opportunities to reduce the risk of complications of cardiovascular disease and atherosclerosis. Despite strong efforts, cardiovascular diseases continue to have a serious impact on public health, increasing 
the level of disability and mortality. In our country with a population of 10 million, in 2018144719 cases of cardiovascular disease were registered among the able-bodied population, 2748 people became disabled and 33309 people died. The most common factor in the development of cardiovascular disease is hypercholesterolemia, its prevalence in the population was (>5 mmol/l) $(78,6 \pm 0,9) \%$ [3].

The European Congress of Cardiologists in Paris (30.09.2019) has updated the recommendations of the European Society of Cardiologists (ESC) and the European Atherosclerosis Society (EAS) on the treatment and diagnosis of dyslipidemia. In the three years since the publication of the previous version of the recommendations, a number of large and significant studies have been completed that have significantly influenced key positions in the new document, so that these studies provide information on the amount of triglycerides, their role in the development of cardiovascular disease, atherosclerosis [4]. Triglycerides play an important role in the vital functions of the body. According to modern research, an increase in the amount of triglycerides in the blood can lead to the development of cardiovascular diseases [5].

According to the largest epidemiological study (Framingham Study), the $1,7 \mathrm{mmol} / \mathrm{l}$ amount of triglycerides is a high risk for the development of cardiovascular diseases [6]. According to NCEP ATP III indicators, normal triglyceride level is $<1,7 \mathrm{mmol} / /$; relatively high level is $(2,3-5,6) \mathrm{mmol} / \mathrm{l}$ and very high level is $>5,6 \mathrm{mmol} / \mathrm{l}[7]$.

Hypertriglyceridemia can be primary and secondary. Hereditary mechanisms play a role in primary hypertriglyceridemia. Secondary hypertriglyceridemia is more common and associated with metabolic diseases. In this case, high levels of triglycerides and low-density lipoprotein (LDL), as well as cholesterol- high-density lipoprotein (HDL) is observed. This condition is called mixed or combined dyslipidemia [8]. According to NHAMES studies, this condition is observed in $62 \%$ of cardiac patients [9]. High level of triglycerides and low level of cholesterol- high-density-lipoprotein (HDL) was $38,8 \%$ in the 22063 patients treated with statins in Europe and $26 \%$ in Canada [10].

So, now it is clinically proven that increased triglyceride (TG) amount plays an important role in the development of cardiovascular diseases [11, 12, 13]. Increased cholesterol (CS) level in the body do not cause triglycerides, but with increased triglyceride amount there is always an increase in cholesterol, especially low-density lipoproteins. When cholesterol and triglyceride levels are elevated in blood plasma, it is necessary to normalize the triglyceride levels first, since this also causes a spontaneous decrease in cholesterol $[14,15,16]$. According to international recommendations, it is recommended to start the drug treatment if the triglyceride level is higher than $2,3 \mathrm{mmol} / \mathrm{l}$ and reduce it to $1,7 \mathrm{mmol} / \mathrm{l}[17,18]$. Non-medication correction should be performed if the triglyceride levels are within the range of 1,7-2,3 $\mathrm{mmol} / \mathrm{l}$ [19].

Although the prevalence of hypercholesterolemia is sufficiently studied at the population level, in many European countries, Russia, the United States and other countries its rate rises to $30 \%$ and higher [20, 21, 22]. However, overweight and obesity are also prevalent in the global population and they also considered to be the leading risk factors for cardiovascular and many other diseases [23, 24, 25].

Aim. To study of the prevalence of hypertriglyceridemia and its importance in the formation of excess weight and obesity at the population level.

Material and methods. A survey of 2013 inhabitants was conducted in Baku. The study was conducted in 3 city polyclinics (patients), 3 secondary schools and 5 kindergartens (parents), as well as 12 trade facilities and offices (employees). An Azerbaijani version of the SF36 International Questionnaire has been compiled and a question-block has been prepared on socio-hygienic aspect, about health and disease [26]. A questionnaire was conducted at the same time with survey, after the relevant explanatory conversation blood was taken from the fingers of the participants' fingers and was checked with the Accutrend Plus portable device and the result was reported within 1-2 minutes. Doctors, nurses, teachers, educators of children's institutions participated in the work. In the questionnaire the participants' body weight index was calculated based on their body and weight indicators $\left(\mathrm{kg} / \mathrm{m}^{2}\right)$. The obtained results were worked out by using a Students -test and a correlation coefficient [27].

Results and discussions. According to the results of the survey, only 216 people of 2013 [(10,7 $\pm 0,7) \%]$ have been tested for triglycerides at different times due to various diseases. Although $(12,1 \pm 0,7] \%$ of them reported cardiovascular diseases, $(32,8 \pm 1,0) \%$ had arterial hypertension, $(25,2 \pm 1,0) \%$ had endocrinological disease, most of them had diabetes, but the results of the survey showed that the majority of the questionnaires were not active in medical application and medical treatment and were reluctant to leave the treatment as soon as the clinical symptoms passed. They postpone outpatient examinations because they are not free and are necessary for them. At the same time after appropriate explanations we were able to involve them in our less time-consuming research and the study was free where we were in contact. The results of the study were presented in Table 1.

HTG was found in 679 of 2013 people [(33,7 $\pm 1,1) \%]$, its level was $1,8-2,2 \mathrm{mmol} / \mathrm{l}$ in $(24,5 \pm 1,0) \%$ cases, $2,3-5,6 \mathrm{mmol} / \mathrm{l}$ in $(7,7 \pm 0,6) \%$ cases, $5,7 \mathrm{mmol} / \mathrm{l}$ higher in $(1,5 \pm 0,2) \%$ cases.

The age-related changes in HTG have been corroborated by correlational dependence. Thus, the triglyceride indicator between 1,8-2,2 $\mathrm{mmol} / \mathrm{l}$ changes consistently with positive dependence at the age of survey participants' from at least age 20 and up to 70 years and older $[r=+(0,94 \pm 0,05) \%]$ and increases from $(17,0 \pm 2,5) \%$ to $(34,5 \pm 3,1) \%(p<0,001)$. With the same positive dependence $(r=+0,88 \pm 0,09)$ in the triglyceride indicator $2,3-5,6 \mathrm{mmol} / \mathrm{l}$ triglycerides consistently change from $(2,6 \pm 1,1) \%$ to $(10,5 \pm 2,0) \%$ $(\mathrm{t}=3,46 ; p<0,001)$. No more than $5,7 \mathrm{mmol} / \mathrm{l}$ triglycerides were found in the respondents under the age of 30 . Consistently, as the age increases, triglyceride indicators increase from $(0,6 \pm 0,3) \%$ to $(3,4 \pm 1,2) \%$ $(\mathrm{t}=2,26 ; p<0,05)$. 
Age-related changes in triglycerides may be attributed to the fact that people become physically less active as they get older and prefer more calorie home foods and more nutrition. All of this leads to excess body weight which plays an important role in the increase in cholesterol and triglyceride concentration in body. The weight of the survey respondents is presented in Table 2.

In $(51,3 \pm 1,1) \%$ of respondents of the survey body weight was normal, but in the rest $(48,7 \pm 1,1) \%$ it was higher than normal $(p<0,05)$. Thus, excess body weight $\left(25,0-29,9 \mathrm{~kg} / \mathrm{m}^{2}\right)$, was found in $(18,9 \pm 0,9) \%$, in $(15,4 \pm 0,8) \%(p<0,001)$ of them first degree obesity $\left(30,0-34,9 \mathrm{~kg} / \mathrm{m}^{2}\right)$, in $(18,6 \pm 0,7) \%(p<0,001)$ of them second degree obesity $\left(35,0-39,9 \mathrm{~kg} / \mathrm{m}^{2}\right)$, in $(3,8 \pm 0,4) \%$ $(p<0,001)$ of them third degree obesity $\left(40,0 \mathrm{~kg} / \mathrm{m}^{2}\right)$ was observed.

Overall, 600 people [(23,8 11,0$) \%]$ have been diagnosed with various degrees of obesity. As hypertriglycerides, obesity indicators also increase depending on age $\left(r^{\prime}=0,89 \pm 0,08\right)$. Basically, if the survey found obesity in 600 out of 41 at the age of $20[(6,8 \pm 1,0) \%]$, the rate increases consistently with age and increases to 93 cases at the age of 70 and older $[(15,6 \pm 1,6) \% ; p<0,001]$. Based on the questions asked, it was found that only 197 people $[(32,8 \pm 1,3) \%]$ consulted a doctor (mainly in first and second degree obesity). Physical activity, morning exercise, running, cycling, swimming, intensive walking and low-calorie food were assigned to all of them, and drug treatment was prescribed to 43 (third degree obesity) of them $[(21,8 \pm 2,9) \%]$. Sustained weight loss was only seen in 718 people $[(9,1 \pm 2,1) \% ; p<0,001]$. The rest of them followed the doctor's prescriptions periodically for no more than 4-5 months which didn't enable the reduction of body weight. Thus, the number of obesity cases was observed on the background of high levels of hypertriglycerides (Table 3).

Table 1

Prevalence of hypertriglyceridemia in different age groups of the population

\begin{tabular}{|l|c|c|c|c|c|c|c|c|c|}
\hline \multirow{2}{*}{$\begin{array}{c}\text { Age } \\
\text { groups, }\end{array}$} & \multirow{2}{*}{$\begin{array}{c}\text { The number of } \\
\text { year }\end{array}$} & \multicolumn{9}{|c|}{ Frequency of different levels of triglycerides } \\
\cline { 3 - 9 } & & \multicolumn{2}{|c|}{$<1,7 \mathrm{mmol} / \mathrm{l}$} & \multicolumn{2}{|c|}{$1,7-2,2 \mathrm{mmol} / \mathrm{l}$} & \multicolumn{2}{|c|}{$2,3-5,6 \mathrm{mmol} / \mathrm{l}$} & \multicolumn{2}{|c|}{$\geq 5,7 \mathrm{mmol} / \mathrm{l}$} \\
\cline { 3 - 10 } & Abs. & $\%$ & Abs. & $\%$ & Abs. & $\%$ & Abs. & $\%$ \\
\hline$<20$ & 230 & 185 & $88,4 \pm 2,6$ & 39 & $17,0 \pm 2,5$ & 6 & $2,6 \pm 1,1$ & - & - \\
$20-29$ & 286 & 220 & $76,9 \pm 2,1$ & 52 & $18,2 \pm 2,0$ & 14 & $4,9 \pm 1,1$ & - & - \\
$30-39$ & 315 & 221 & $70,2 \pm 2,6$ & 71 & $22,5 \pm 2,4$ & 21 & $6,7 \pm 1,4$ & 2 & $0,6 \pm 0,3$ \\
$40-49$ & 327 & 219 & $67,0 \pm 1,9$ & 76 & $23,2 \pm 2,3$ & 29 & $8,9 \pm 1,6$ & 3 & $0,9 \pm 0,5$ \\
$50-59$ & 314 & 194 & $61,8 \pm 2,7$ & 85 & $27,1 \pm 2,6$ & 26 & $8,3 \pm 1,6$ & 9 & $2,9 \pm 0,9$ \\
$60-69$ & 303 & 172 & $56,8 \pm 2,9$ & 88 & $23,0 \pm 2,6$ & 34 & $11,2 \pm 1,8$ & 9 & $3,0 \pm 1,0$ \\
$\geq 70$ & 238 & 123 & $51,7 \pm 3,2$ & 82 & $34,5 \pm 3,1$ & 25 & $10,5 \pm 2,0$ & 8 & $3,4 \pm 1,2$ \\
\hline Total & 2013 & 1334 & $66,3 \pm 1,1$ & 493 & $24,5 \pm 1,0$ & 155 & $7,7 \pm 0,6$ & 31 & $1,5 \pm 0,2$ \\
\hline
\end{tabular}

Table 2

Prevalence of excess body weight and obesity in different age groups of the population

\begin{tabular}{|c|c|c|c|c|c|c|c|c|c|c|c|}
\hline \multirow{3}{*}{$\begin{array}{c}\text { Age } \\
\text { groups, } \\
\text { year }\end{array}$} & \multirow{3}{*}{$\begin{array}{c}\text { The } \\
\text { number of } \\
\text { participants }\end{array}$} & \multicolumn{10}{|c|}{ Detection frequency of different levels of excess body weight and obesity } \\
\hline & & \multicolumn{2}{|c|}{$<25,0 \mathrm{~kg} / \mathrm{m}^{2}$} & \multicolumn{2}{|c|}{$25,0-29,9 \mathrm{~kg} / \mathrm{m}^{2}$} & \multicolumn{2}{|c|}{$30,0-34,9 \mathrm{~kg} / \mathrm{m}^{2}$} & \multicolumn{2}{|c|}{$35,0-39,9 \mathrm{~kg} / \mathrm{m}^{2}$} & \multicolumn{2}{|c|}{$\geq 40,0 \mathrm{~kg} / \mathrm{m}^{2}$} \\
\hline & & Abs. & $\%$ & Abs. & $\%$ & Abs. & $\%$ & Abs. & $\%$ & Abs. & $\%$ \\
\hline$<20$ & 230 & 137 & $59,6 \pm 3,2$ & 52 & $22,6 \pm 2,8$ & 27 & $11,7 \pm 2,1$ & 14 & $6,1 \pm 1,6$ & - & - \\
\hline $20-29$ & 286 & 158 & $55,2 \pm 2,9$ & 68 & $23,8 \pm 2,5$ & 35 & $12,2 \pm 1,9$ & 25 & $8,7 \pm 1,7$ & - & - \\
\hline $30-39$ & 315 & 172 & $54,6 \pm 2,8$ & 70 & $22,2 \pm 2,3$ & 40 & $12,7 \pm 1,9$ & 29 & $9,2 \pm 1,6$ & 4 & $1,3 \pm 0,6$ \\
\hline $40-49$ & 327 & 164 & $50,2 \pm 2,8$ & 75 & $22,9 \pm 2,3$ & 48 & $14,7 \pm 2,0$ & 32 & $9,8 \pm 1,6$ & 8 & $2,4 \pm 0,8$ \\
\hline $50-59$ & 314 & 150 & $47,8 \pm 2,8$ & 51 & $16,2 \pm 2,1$ & 57 & $18,2 \pm 2,2$ & 32 & $10,2 \pm 1,7$ & 24 & $7,6 \pm 1,5$ \\
\hline $60-69$ & 303 & 145 & $47,9 \pm 2,9$ & 32 & $18,6 \pm 1,8$ & 58 & $19,1 \pm 2,3$ & 46 & $15,2 \pm 2,1$ & 22 & $7,3 \pm 1,5$ \\
\hline$\geq 70$ & 238 & 106 & $44,5 \pm 3,2$ & 33 & $13,9 \pm 2,2$ & 46 & $19,3 \pm 2,6$ & 35 & $14,7 \pm 2,3$ & 18 & $7,6 \pm 1,7$ \\
\hline Total & 2013 & 1032 & $51,3 \pm 1,1$ & 381 & $18,9 \pm 0,9$ & 311 & $15,4 \pm 0,8$ & 213 & $10,6 \pm 0,7$ & 76 & $3,8 \pm 0,4$ \\
\hline
\end{tabular}

Ta ble 3

Mutual dependence of prevalence of hypertriglycerides, excess body weight and obesity

\begin{tabular}{|c|c|c|c|c|c|c|c|c|c|c|}
\hline \multirow{3}{*}{$\begin{array}{l}\text { Body weight, } \\
\mathrm{kg} / \mathrm{m}^{2}\end{array}$} & \multirow{2}{*}{\multicolumn{2}{|c|}{ Body weight frequency }} & \multicolumn{8}{|c|}{ Frequency of different levels of triglycerides } \\
\hline & & & \multicolumn{2}{|c|}{$<1,7 \mathrm{mmol} / \mathrm{l}$} & \multicolumn{2}{|c|}{$1,7-2,2 \mathrm{mmol} / \mathrm{l}$} & \multicolumn{2}{|c|}{$2,3-5,6 \mathrm{mmol} / \mathrm{l}$} & \multicolumn{2}{|c|}{$\geq 5,7 \mathrm{mmol} / \mathrm{l}$} \\
\hline & Abs. & $\%$ & Abs. & $\%$ & Abs. & $\%$ & Abs. & $\%$ & Abs. & $\%$ \\
\hline$<25,0$ & 1032 & $51,3 \pm 1,1$ & 906 & $87,8 \pm 1,0$ & 120 & $11,6 \pm 1,0$ & 6 & $0,6 \pm 0,2$ & - & - \\
\hline $25,0-29,9$ & 381 & $18,9 \pm 0,9$ & 279 & $73,2 \pm 2,3$ & 96 & $25,1 \pm 2,2$ & 6 & $1,6 \pm 0,6$ & - & - \\
\hline $30,0-34,9$ & 311 & $15,4 \pm 0,8$ & 126 & $40,5 \pm 2,8$ & 161 & $51,8 \pm 2,8$ & 21 & $6,8 \pm 1,4$ & 3 & $1,0 \pm 0,5$ \\
\hline $35,0-39,9$ & 213 & $10,6 \pm 0,7$ & 23 & $10,8 \pm 2,1$ & 116 & $54,5 \pm 3,4$ & 60 & $28,1 \pm 3,1$ & 14 & $6,6 \pm 1,7$ \\
\hline$\geq 40,0$ & 76 & $3,8 \pm 0,4$ & - & - & - & - & 62 & $81,6 \pm 4,5$ & 14 & $38,4 \pm 4,5$ \\
\hline Total & 2013 & $100,0 \pm 0,0$ & 1334 & $66,3 \pm 1,1$ & 493 & $24,5 \pm 1,0$ & 155 & $7,7 \pm 0,6$ & 31 & $1,5 \pm 0,2$ \\
\hline
\end{tabular}


All obesity cases were observed in the people with hypertriglyceride indicator of more than $2,3 \mathrm{mmol} / \mathrm{l}$. Thus, third degree obesity wasn't observed in the people with hypertriglyceride indicator of $<2,3 \mathrm{mmol} / \mathrm{l}$. The table shows that there is a dependence between body weight and the concentration of triglycerides in the body. For example, normal body weight in triglyceride level of $1,7-2,3 \mathrm{mmol} / \mathrm{l}$ was observed only in $(11,6 \pm 1,0) \%$ of the survey participants. At this level of hypertriglycerides excess weight $(25,1 \pm 2,2) \%(p<0,01)$, especially first and second degree obesity, and according to this, $(51,8 \pm 2,8) \%(p<0,001)$ and $(54,5 \pm 3,4) \%(p<0,05)$ cases were observed. At $2,3-5,6 \mathrm{mmol} / \mathrm{l}$ level of hypertriglycerides these indicators rise from $(0,6 \pm 0,2) \%$ to $(83,6 \pm 4,5) \%(p<0,001)$. In general, as mentioned above, 451 different degrees of obesity have been observed together with high levels of triglycerides.

Conclusion. Mentions above let us tell that hypertriglyceridemia, together with low physical activity and inadequate nutritional behavior play an important role in the formation of excess weight and obesity. If we take into account that due to international recommendations medication must be taken when hypertriglyceridemia are less than $2,3 \mathrm{mmol} / \mathrm{l}$, statins used in this regard will also help to improve obesity rates. Other measures to improve obesity, extension of physical activity and normalization of nutritional behavior will also help in the reduction of hypertriglyceridemia. In this regard, it is important to improve the forms of information-explanatory work to increase the population's motivation to correct these risk factors. The importance of this work is also based on the fact that hypertriglyceridemia and obesity are often found together, and their interaction increases the risk of developing cardiovascular diseases (at the population level).

Transparency. The study did not have sponsorship. The authors are fully responsible for the submission of the final version of the manuscript.

Financial and other relationships declaration. All authors participated in concept and design of the article and manuscript writing. The final version of the manuscript was approved by all authors. Authors did not receive fees for research.

\section{ЛИТЕРАТУРА}

1. WHO newsletter. Cardiovascular diseases [cited by Apr 20 , 2019]. - URL: https://www.who.int/news-room/fact-sheets/ detail/cardiovascular-diseases-(cvds).

2. Taylor, J. SWEDEHEART: Sweden's new online cardiac registry, the first of its kind / J. Taylor // Eur. Heart J. 2009. - Vol. 30. - P.2165-2173.

3. Гаджиева, Ю.Х. Характер и частота распространенности гиперхолестеринемии среди городских жителей / Ю.Х. Гаджиева // Медицинские новости. - 2018. № 12. - C.62-64.

4. ESC / EAS 2019 recommendations for the diagnosis and treatment of dyslipidemia: a review of the changes (30.09.2019, Paris). - URL: https://www.escardio.org/ Guidelines/Clinical-Practice-Guidelines/DyslipidaemiasManagement-of
5. Nordestgaard, B.G. Triglycerides and cardiovascular disease / B.G. Nordestgaard, A. Varbo // Lancet. - 2014. Vol. 384 (9943). - P.626-635.

6. Castelli, W.P. Epidemiology of triglycerides: a view from Framingham / W.P. Castelli // Am. J. Cardiol. - 1992. Vol. 70 (19). - P.3H-9H.

7. National Cholesterol Education Program. Third Report ofthe National Cholesterol Education Program (NCEP) Expert Panel on Detection, Evaluation, and Treatmentof High Blood Cholesterol in Adults (Adult Treatment Panel III). Final Report / S.M. Grundy, D. Becker, L.T. Clark [et al.]. - NIH Publication, 2002. - № 02-5215.

8. Review of the evidence on reducing macrovascular risk in patients with atherogenicdyslipidaemia: A report from an expert consensus meeting on the role of fenofibratestatin combination therapy / C. Aguiar, E. Alegria, R.C. Bonadonna [et al.] // Atheroscler Suppl. - 2015. Vol. 19. -P.1-12.

9. Ghandehari, H. Prevalence and extent of dyslipidemia and recommended lipid levels in US adults with and without cardiovascular comorbidities: The National Health and Nutrition Examination Survey 2003-2004 / H. Ghandehari, S. Kamal-Bahl, N.D. Wong // Am. Heart J. - 2008. Vol. 156 (1). - P.112-119.

10. DYSIS Investigators. Persistent lipid abnormalities in statin-treated patients and predictors of LDL-cholesterol goal achievement in clinical practice in Europe and Canada / A.K. Gitt, H. Drexel, J. Feely [et al.] // Eur. J. Prev. Cardiol. - 2012. - Vol. 19 (2). - P.221-230.

11. Contibution of high plasma triglyserides and low highdensity lipoprotein cholesterol to residual risk of coronary heart disease after establishment of low-density lipoprotein cholesterol control / V.J. Carey, L. Bishop, N. Laranjo [et al.] // Am. J. Cardiol. - 2010. - Vol. 106 (6). -P.757-763.

12. Tuтов, В.Н. Филогенетическая теория общей патологии. Патогенез метаболических пандемий. Атеросклероз / В.Н. Титов. - М.: ИНФРА-М, 2014. - 335 с.

13. Kohan, A.B. Apolipoprotein C-III: a potent modulator of hypertriglyceridemia and cardiovascular disease / A.B. Kohan // Curr. Opin. Endocrinol. Diabetes Obes. 2015. - Vol. 22 (2). - P.119-25.

14. Comparison of the abilities of the plasma triglyseride/ high-density lipoprotein cholesterol ratio and the metabolic syndrome to identify insulin resistance / M.R. Salazar, H.A. Carbajal, W.G. Espeche [et al.] // Diab. Vasc. Dis. Res. - 2013. -Vol. 10 (4). - P.346-352.

15. Palm oil and blood lipid-related markers of cardiovascular disease: a systematic review and meta-analysis of dietary intervention trials / E. Fattore, C. Bosetti, F. Brighenti [et al.] // Am. J. Clin. Nutr. - 2014. -Vol. 99 (6). - P.1331-1350.

16. Титов, В.Н. Этиология и патогенез последовательного становления тестов гипертриглицеридемии, гиперхолестеринемии и гипергликемии. Общность этиологических факторов метаболических пандемий и компенсаторная роль APOS-III / В.Н. Титов // Клиническая лабораторная диагностика. - 2016. - Т. 61, № 1. - C.4-12. 
17. 2016 ESC/EAS guidelines for the management of dyslipidaemias / A.L. Catapano, I. Graham, G. De Backer [et al.] // Eur. Heart J. - 2016. - Vol. 37 (39). - P.2999-3058.

18. Диагностика и коррекция нарушений липидного обмена с целью профилактики и лечения атеросклероза. Российские рекомендации. VI пересмотр / М.В. Ежов, И.В. Сергиенко, Д.М. Аронов [и др.] // Атеросклероз и дислипидемии. - 2017. - № 3 (28).-С.5-28.

19. Hypertriglycerdemia as the Way to Reduce Residual Risk in Diseases Caused by Atherosderosis. Condusion of the Advisory Board of the Russia. Society of Cardiology, the Russian Scientific Medical Society of Therapists, the Eurasian Association of Therapists, the Russian National Atherosclerosis Society, the Russian Association of Endocrinologists, and the National League of Cardiologic Genetics / G.P. Arutyunov, S.A. Boytsov, M.I. Voyevoda [et al.] // Rational Pharnacotherapy in Cardiology. - 2019. Vol. 15 (2). - P.282-288.

20. Triglycerides and cardiovascular disease: a sclentific statement from the American Heart Association / M. Miller, N.J. Stone, C. Ballantyne [et al.] // Circulation. - 2011. Vol. 123. -P.2292-2333.

21. Tenenbaum, $A$. Hypertrigiyceridemia a too long unfairly neglected major cardiovascular risk factor / A. Tenenbaum, R. Klempfner, E.Z. Fisman // Cardiovasc. Diabetol. 2014. -Vol. 13. - P.159.

22. Карпов, Ю.А. Распространенность гипертриглицеридемии: новые всероссийские данные. Исследование PROMETHEUS / Ю.А. Карпов // Кардиология. - 2016. - T. 56, № 7. - C.63-71. - DOI: 10.18565/ cardio.2016.7.63-71.

23. Patchy progress on obesity prevention: emerging examples, entrenched barriers, and new thinking / C.A. Roberto, B. Swinburn, C. Hawkes [et al.] // Lancet. Elsevier. - 2015. -Vol. 385. - P.9985:2400-9.

24. Booth H.P. Severity of obesity and management of hypertension, hypercholesterolaemia and smoking in primary care: population - based cohort study / H.P. Booth, A.T. Prevost, M.C. Gulliford // J. Hum. Hypertens. - 2016. Vol. 30. -P. 40-45.

25. Баланова, Ю.А. Распространенность ожирения среди населения России и его связь с факторами риска неинфекционных заболеваний / Ю.А. Баланова, С.А. Шальнова, А.Д. Деев [и др.] // Кардиология. - 2018. -Т. 23 , № 6. -C.123-130.

26. Ware Kosinski, M. SF-36 physical and mental health summary: scales a user's manual / M. Ware Kosinski, S. Keller. - Boston, Mass: The Health Institute, 1994. $217 \mathrm{p}$.

27. Glanz, S. Primer of biostatistics.Fourth edition / S. Glanz. NY: McGRAW-HIL Linc, 1997. - 473 p.

\section{REFERENCES}

1. WHO newsletter. Cardiovascular diseases [cited by Apr 20, 2019]. 2019; https://www.who.int/news-room/fact-sheets/ detail/cardiovascular-diseases-(cvds).

2. Taylor J. SWEDEHEART: Sweden's new online cardiac registry, the first of its kind. Eur Heart J. 2009; 30: 21652173.
3. Gadzhieva YuKh. Harakter i chastota rasprostranennosti giperholesterinemii sredi gorodskih zhitelej [The character and frequency of hypercholesterinemia among urban population.]. Meditsinskie novosti [Medical News]. 2018; 12: 62-64.

4. ESC / EAS 2019 recommendations for the diagnosis and treatment of dyslipidemia: a review of the changes (30.09.2019, Paris). 2019; https://www.escardio.org/ Guidelines/Clinical-Practice-Guidelines/DyslipidaemiasManagement-of

5. Nordestgaard BG, Varbo A. Triglycerides and cardiovascular disease. Lancet. 2014; 384 (9943): 626-635.

6. Castelli WP. Epidemiology of triglycerides: a view from Framingham. Am J Cardiol. 1992; 70 (19): 3H-9H. doi:10.1016/0002-9149(92)91083-G.

7. Grundy SM, Becker D, Clark LT, et al. National Cholesterol Education Program. Third Report ofthe National Cholesterol Education Program (NCEP) Expert Panel on Detection, Evaluation, and Treatment of High Blood Cholesterol in Adults (Adult Treatment Panel III); Final Report, September 2002. NIH Publication. 2002; 02: 5215.

8. Aguiar C, Alegria E, Bonadonna RC, et al. A review of the evidence on reducing macrovascular risk in patients with atherogenic dyslipidaemia: A report from an expert consensus meeting on the role of fenofibrate-statin combination therapy. Atheroscler Suppl. 2015; 19: 1-12. doi:10.1016/S1567-5688(15)30001-5.

9. Ghandehari H, Kamal-Bahl S, Wong ND. Prevalence and extent of dyslipidemia and recommended lipid levels in US adults with and without cardiovascular comorbidities: The National Health and Nutrition Examination Survey 20032004. Am Heart J. 2008; 156 (1): 112-119. doi:10.1016/j. ahj.2008.03.005.

10. Gitt AK, Drexel H, Feely J, et al. DYSIS Investigators. Persistent lipid abnormalities in statin-treated patients and predictors of LDL-cholesterol goal achievement in clinical practice in Europe and Canada. Eur J Prev Cardiol. 2012; 19 (2): 221-230. doi:10.1177/1741826711400545.

11. Carey VJ, Bishop L, Laranjo N, et al. Contibution of high plasma triglyserides and low high-density lipoprotein cholesterol to residual risk of coronary heart disease after establishment of low-density lipoprotein cholesterol control. Am J Cardiol. 2010; 106 (6): 757-763. doi: 10.1016 j.amjcard.2010.05.002.

12. Titov VN. Filogeneticheskaya teoriya obshchej patologii; Patogenez metabolicheskih pandemij; Ateroskleroz [Phylogenetic Theory of General Pathology; The Pathogenesis of the Diseases of Civilization; Atheroscleroses]. Moskva: INFRA-M [Moscow: INFRA-M]. 2014; $222 \mathrm{p}$.

13. Kohan AB. Apolipoprotein C-III: a potent modulator of hypertriglyceridemia and cardiovascular disease. Curr Opin Endocrinol Diabetes Obes. 2015; 22 (2): 119-125.

14. Salazar MR, Carbajal HA, Espeche WG, Leiva Sisnieguez CE, March CE, Balbin E, et al. Comparison of the abilities of the plasma triglyseride /high - density lipoprotein cholesterol ratio and the metabolic syndrome to identify insulin resistance. Diab Vasc Dis Res. 2013; 10 (4): 346-352. 
15. Fattore E, Bosetti C, Brighenti F, Agostoni C, Fattore G. Palm oil and blood lipid-related markers of cardiovascular disease: a systematic review and meta-analysis of dietary intervention trials. Am J Clin Nutr. 2014; 99 (6): 1331-1350.

16. Titov VN. Etiologiya i patogenez posledovatel'nogo stanovleniya testov gipertrigliceridemii, giperholesterinemii i giperglikemii; Obshchnost' etiologicheskih faktorov metabolicheskih pandemij i kompensatornaya rol' APOSIII [The etiology and pathogenesis of successive making test on hypertriglyceridemia, hypercholesterolemia and hypoglycemia; The common character of etiologic factors of metabolic pandemic and compensatory role of APOSIII]. Klinicheshaya laboratornaya diagnostika [Clinical laboratory diagnostics]. 2016; 61 (1): 4-12.

17. 17. Catapano AL, Graham I, De Backer G, et al. 2016 ESC/ EAS guidelines for the management of dyslipidaemias. Eur Heart J. 2016; 37 (39): 2999-3058. doI: 10.1093/ eurheartj/ehw272.

18. Ezhov MV, Sergienko IV, Aronov DM, et al. Diagnostika i korrekciya narushenij lipidnogo obmena s cel'yu profilaktiki i lecheniya ateroskleroza; Rossijskie rekomendacii; VI peresmotr [Diagnosis and correction of lıpıd metabolısm disorders for the prevention and treatment of atherosclerosis]. Ateroskleroz i dislipidemii [Atherosderosis and Dyslipidemia]. 2017; 3 (28): 5-28.

19. Arutyunov GP, Boytsov SA, Voyevoda MI, et al. Hypertriglycerdemia as the Way to Reduce Residual Risk in Diseases Caused by Atherosderosis; Condusion of the Advisory Board of the Russıa. Society of Cardiology, the Russian Scientific Medical Society of Therapists, the Eurasian Association of Therapists, the Russian National Atherosclerosis Society, the Russian Association of Endocrinologists, and the National League of Cardiologic Genetics. Rational Pharnacotherapy in Cardiology. 2019; 15 (2): 282-288. DOI: 10.20996/1819-6446-2019-15-2282-288
20. Miller M, Stone NJ, Ballantyne C, Bittner V, Criqul MH, Ginsberg HN, et al. Triglycerides and cardiovascular disease: a sclentific statement from the American Heart Association. Circulation. 2011; 123: 2292-2333.

21. Tenenbaum A, Klempfner R, Fisman EZ. Hypertrigiyceridemia a too long unfairly neglected major cardiovascular risk factor. Cardiovasc Diabetol. 2014; 13: 159.

22. Karpov YuA. Rasprostranennost' gipertrigliceridemii: novye dannye sredi naseleniya Rossii; Issledovanie PROMETEJ [Prevalence of Hypertriglyceridemia: New Data Across the Russian Population; The PROMETHEUS Study]. Kardiologiya [Cardiology]. 2016; 56 (7): 63-71.

23. Roberto CA, Swinburn B, Hawkes C, et al. Patchy progress on obesity prevention:emerging examples, entrenched barriers, and new thinking. Lancet: Elsevier. 2015; 385 (9985): 2400-2409. DOI: 10.1016/SO1406736(14)61744-X.

24. Booth HP, Prevost AT, Gulliford MC. Severity of obesity and management of hypertension, hypercholesterolaemia and smoking in primary care: population -based cohort study. J Hum Hypertens. 2016; 30: 40-45. DOI: 10.1038/ jhh.2015.23.

25. Balanova YuA, Shalnova SA, Deev AD, et al. Rasprostranennost' ozhireniya sredi naseleniya Rossii i ego svyaz's faktorami riska neinfekcionnyh zabolevanij [Obesity in Russian pooulation-prevalences and association the non-communicable diseases risk factors]. Kardiologiya [Russ J Cardiol]. 2018; 23 (6): 123-130. http:// dx.doi.org/10.15829/1560-4071-20186-123-130

26. Ware Kosinski M, Keller S. SF-36 physical and mental health summary: scales a user"s manual. Boston, Mass: The Health Institute. 1994; 217 p.

27. Glanz S. Primer of biostatistics; Fourth edition. NY: McGRAW-HILL inc. 1997; 473 p. 